\title{
Efisiensi irigasi berdasarkan kondisi saluran di daerah irigasi Punggur Utara
}

\author{
Dwi Meyta Sari a, Endro Prasetyo Wahono ${ }^{\text {b, }}$, Dyah Indriana Kusumastutic \\ ${ }^{a}$ Mahasiswa Magister Teknik Sipil, Universitas Lampung, Jl. Soemantri Brojonegoro No. 1 Bandar Lampung, 35145, Indonesia \\ ${ }^{b}$ Jurusan Teknik Sipil, Universitas Lampung, Jl. Soemantri Brojonegoro No. 1 Bandar Lampung, 35145, Indonesia \\ c Jurusan Teknik Sipil, Universitas Lampung, Jl. Soemantri Brojonegoro No. 1 Bandar Lampung, 35145, Indonesia
}

\section{H I G H L I G H T S}

- Penelitian tentang efisiensi irigasi di daerah irigasi BPU 15 Kecamatan Punggur Utara Kabupaten Lampung Tengah telah dilakukan.

- Faktor yang menyebabkan kehilangan air adalah rembesan, evaporasi dan faktor lain (pencurian air).

- Perlu perawatan fasilitas irigasi seperti kebersihan saluran irigasi dari sampah dan rumput sehingga efisiensi irigasi dapat ditingkatkan.

\section{N F O A R T I K E L}

\section{Riwayat artikel:}

Diterima 12 April 2020

Diterima setelah diperbaiki 17 Mei 2020

Diterima untuk diterbitkan 10 Juni 2020

Tersedia secara online 01 Agustus 2020

\section{Kata kunci:}

Kondisi saluran,

efisiensi irigasi,

evaporasi,

rembesan.

\begin{abstract}
A B S T R A K
Air irigasi dalam perjalanannya untuk sampai ke petakan sawah mengalami kehilangan air yang dapat disebabkan oleh beberapa faktor diantaranya rembesan, evaporasi dan faktor lain seperti adanya eksploitasi air irigasi oleh warga sekitar. Tujuan penelitian ini adalah untuk mengetahui kondisi fisik saluran sekunder di BF 3 sampai dengan BF 5 dan nilai efisiensi yang tercapai, serta untuk mengetahui besar kehilangan air akibat faktor rembesan, evaporasi dan faktor lainnya. Penelitian ini dilakukan dengan mengidentifikasi kondisi saluran, menghitung efisiensi yang tercapai dan kehilangan air. Hasil penelitian menunjukkan bahwa kerusakan pada saluran BF 3 - BF 4 termasuk dalam kategori rusak ringan dengan efisiensi rata - rata yang tercapai sebesar 97,41\%. Persentase kehilangan air pada saluran BF 3 - BF 4 akibat faktor rembesan sebesar $53,74 \%$, faktor evaporasi sebesar $0,69 \%$ dan faktor lain - lainnya sebesar $46,57 \%$. Sedangkan kondisi pada saluran BF 4 - BF 5 termasuk ke dalam kategori baik dengan efisiensi yang tercapai sebesar $87,44 \%$. Persentase kehilangan air pada saluran BF 4 - BF 5 akibat faktor rembesan sebesar $27,85 \%$, faktor evaporasi sebesar $0,78 \%$ dan faktor lain - lainnya sebesar 71,37\%.
\end{abstract}

Diterbitkan oleh Jurusan Teknik Sipil Universitas Lampung

\section{Pendahuluan}

Salah satu aktivitas yang sangat erat kaitannya dengan pemanfaatan sumber daya air adalah dari sektor pertanian. Irigasi merupakan salah satu usaha pendayagunaan air untuk mengurangi resiko kegagalan panen karena ketidakpastian hujan dan kekeringan. Selain itu irigasi memberikan banyak manfaat antara lain membuat unsur hara yang tersedia menjadi lebih baik, menciptakan kondisi kelembaban tanah optimum untuk pertumbuhan tanaman, serta hasil dan kualitas tanaman yang lebih baik [1].

Menurut Sutrisno dan Chayati [2] debit air irigasi dalam perjalanannya untuk sampai ke sawah menempuh puluhan

\footnotetext{
* Penulis koresponden.

Alamat e-mail: epwahono@eng.unila.ac.id (E.P. Wahono). Peer review dibawah tanggung-jawab Jurusan Teknik Sipil Universitas Lampung.
}

kilometer sehingga bukan tidak mungkin apabila air irigagasi mengalami kehilangan - kehilangan selama perjalanan dari saluran pembawa sampai saluran tersier. Menurut hasil penelitian yang mereka lakukan ada beberapa faktor yang menyebabkan kehilangan air diantaranya evaporasi, perkolasi, adanya penyadapan air, dan kerusakan bangunan pada saluran irigasi. Hal inilah yang menyebabkan efisiensi penggunaaan air tidak dapat maksimal.

Sembiring [3] melakukan penelitian tentang analisis debit air irigasi (suplai dan kebutuhan) di Sekampung Sistem. Penelitian ini menunjukkan bahwa kondisi dan kemampuan saluran irigasi yang ada di Sekampung Sistem mengalami penurunan yang cukup signifikan secara fungsi pengaliran. Hal ini disebabkan karena terjadi banyak kerusakan (berat, sedang dan ringan) di saluran pembawa, saluran primer dan saluran sekunder yang ada di setiap daerah irigasi (DI) yang ada di Sekampung Sistem.

Tujuan penelitian ini adalah untuk mengetahui kondisi fisik saluran sekunder di BF 3 sampai BF 5, nilai efisiensi 
yang tercapai dan besar kehilangan air akibat faktor rembesan, evaporasi dan faktor lainnya.

\section{Tinjauan Pustaka}

Irigasi adalah usaha untuk memperoleh air yang menggunakan bangunan dan saluran buatan untuk keperluan produksi pertanian. Usaha yang dilakukan tersebut dapat meliputi antara lain mulai dari perencanaan, kemudian pembuatan, pengelolaan, serta pemeliharaan sarana untuk mengambil air yang diperoleh dari sumber air dan membagi air tersebut secara teratur kemudian apabila terjadi kelebihan air dengan membuangnya melalui saluran pembuang ataupun saluran drainase [4]. Sedangkan air irigasi yang masuk ke lahan pertanian dapat diketahui berdasarkan debit air yang mengalir pada daerah tersebut. Debit dapat didefinisikan sebagai volume air yang mengalir melalui suatu penampang melintang pada alur, pipa ataupun akuifer ambang per satuan waktu (liter/detik) [5].

Efisiensi irigasi menunjukkan angka daya guna pemakaian air yaitu merupakan perbandingan antara jumlah air yang digunakan dengan jumlah air yang diberikan yang dinyatakan dalam persen (\%). Dengan asumsi bahwa jika angka kehilangan air naik maka efisiensi akan turun dan begitu juga sebaliknya [6]. Menurut Siswoyo [7] secara fisik hal pertama yang mempengaruhi efisiensi adalah kondisi dari saluran itu sendiri. Selain itu secara teoritis, parameter yang berpengaruh terhadap nilai efisiensi antara lain rembesan dan bocoran, bentuk penampang saluran dan jenis material, evaporasi, sedimentasi dan longsoran.

\section{Metode Penelitian}

Penelitian ini dilakukan di Daerah Irigasi BPU 15 Kecamatan Punggur Utara, Kabupaten Lampung Tengah di Saluran Sekunder BF 3 sampai dengan BF 5. Survei pendahuluan dilakukan untuk menentukan daerah mana yang akan dipilih sebagai titik lokasi penelitian dan mengamati keadaan daerah serta kondisi lokasi penelitian. Langkah selanjutnya yaitu studi pustaka yaitu dengan mengumpulkan, mengidentifikasi serta mengetahui sistem kerja yang dapat digunakan mengenai teori-teori yang berkaitan dengan pokok permasalahan. Survei lapangan dilakukan untuk medapatkan data primer dengan cara melakukan pengukuran langsung menggunakan alat current meter. Selain itu agar mengetahui secara terperinci keadaan di lapangan, kegiatan manusia, situasi sosial dan kontak kegiatan. Data yang diperoleh bersifat deskriptif dan faktual. Data sekunder berupa data curah dan klimatologi tahun 2018 yang bersumber dari Stasiun Meteorologi Radin Inten II. Setelah semua data terkumpul langkah selanjutnya adalah menganalisis kondisi saluran, efisiensi saluran dan kehilangan air.

\section{Hasil dan Pembahasan}

\subsection{Penilaian kondisi fisik saluran}

Untuk mengetahui bagaimana kondisi fisik saluran saat ini, penilaian pada aspek fisik dilakukan dengan cara melakukan pengamatan atau observasi terhadap sub - sub bagian dari saluran. Kerusakan tanah dapat dinilai dengan mengamati ada atau tidaknya rembesan/bocoran, berlubang, roboh/longsor dengan hasil disajikan pada Table 1 .
Tabel 1

Penilaian kerusakan saluran BF 3 - BF 4

\begin{tabular}{lllll}
\hline No & $\begin{array}{l}\text { Panjang } \\
\text { saluran }(\mathrm{m})\end{array}$ & $\begin{array}{l}\text { Kerusakan } \\
(\%)\end{array}$ & Skor & $\begin{array}{l}\text { Kategori } \\
\text { kerusakan }\end{array}$ \\
\hline 1 & BF3 Hilir -100 & $34 \%$ & 2 & Rusak sedang \\
2 & 100 & $8 \%$ & 4 & Baik \\
3 & 100 & $9 \%$ & 4 & Baik \\
4 & 100 & $29 \%$ & 2 & Rusak sedang \\
5 & 112 & $13 \%$ & 3 & Rusak ringan \\
Tot. & 512 & $19 \%$ & 3 & Rusak ringan \\
\hline
\end{tabular}

Tabel 1 menunjukkan bahwa kerusakan saluran total pada segmen ini sebesar $19 \%$ dan termasuk dalam kategori rusak ringan. Hal tersebut menjelaskan bahwa saluran masih dapat bekerja dengan baik, walaupun mengalami kerusakan sepanjang 95,2 meter. Panjang saluran ini adalah $512 \mathrm{~m}$ dengan luas areal sawah yang dilayani sebesar 323 ha. Berdasarkan hasil survey dan pengamatan langsung di lapangan, bahwa di saluran BF 3 - BF 4 tidak terdapat bangunan lining, bangunan konstruksi pada saluran ini hanya berupa tanah dasar. Selain itu di sekitar saluran terdapat tumbuhan semak belukar yang merupakan tumbuhan yang banyak memerlukan air, sehingga air yang merembes dari saluran akan diserap oleh akar tanaman.

Tabel 2 menunjukkan bahwa kerusakan struktur total pada segmen ini sebesar $5 \%$ dan termasuk kedalam kategori baik. Hal tersebut menjelaskan bahwa saluran dapat bekerja dengan baik, walaupun mengalami kerusakan sepanjang 99 meter. Panjang saluran ini adalah $1.810 \mathrm{~m}$ dengan luas areal sawah yang dilayani sebesar 226 ha. Berdasarkan hasil survei, pada saluran tersebut terdapat bangunan lining sepanjang 490 meter dan masih dalam kondisi yang baik karena sedikit terjadi kerusakan pada lining tersebut. Hanya saja, selain kondisi tersebut saluran hilir BF 5 dipenuhi oleh tumpukan sampah sehingga menghambat aliran air ke saluran irigasi yang disebabkan karena kurangnya kesadaran masyarakat dalam menjaga jaringan irigasi.

Tabel 2

Penilaian kerusakan BF 4 - BF 5

\begin{tabular}{lllll}
\hline No & $\begin{array}{l}\text { Panjang } \\
\text { saluran }(\mathrm{m})\end{array}$ & $\begin{array}{l}\text { Persentase } \\
\text { kerusakan }\end{array}$ & Skor & $\begin{array}{l}\text { Kategori } \\
\text { kerusakan }\end{array}$ \\
\hline 1 & 200 & $8 \%$ & 4 & Baik \\
2 & 200 & $3 \%$ & 4 & Baik \\
3 & 200 & $6 \%$ & 4 & Baik \\
4 & 200 & $16 \%$ & 3 & Rusak ringan \\
5 & 200 & $8 \%$ & 4 & Baik \\
6 & 200 & $6 \%$ & 4 & Baik \\
7 & 200 & $3 \%$ & 4 & Baik \\
8 & 200 & 0 & 4 & Baik \\
9 & 210 & 0 & 4 & Baik \\
Total & 1080 & $5 \%$ & 3 & Baik \\
\hline
\end{tabular}

\subsection{Analisis efisiensi saluran}

Efisiensi saluran didefinisikan sebagai perbandingan antara jumlah air yang masuk pada hulu saluran dengan jumlah air yang tersedia pada hilir yang dinyatakan dalam persentase. Pengukuran dilakukan dengan menggunakan simulasi bukaan pintu mulai dari ditutup kemudian bukaan $2 \mathrm{~cm}, 4 \mathrm{~cm}, 6 \mathrm{~cm}, 8 \mathrm{~cm}, 10 \mathrm{~cm}$, dan seterusnya sampai dengan bukaan $40 \mathrm{~cm}$ menggunakan current meter.

Berdasarkan hasil perhitungan di saluran irigasi BF3 BF 4 di Tabel 3, menunjukkan bahwa efisiensi terkecil terjadi pada saluran BF 3 Hilir dengan nilai efisiensi sebesar 98,88\% dan efisiensi terbesar terjadi pada saluran STA + 
200 dengan nilai efisiensi sebesar 99,90\%. Efisiensi rata rata yang tercapai untuk tiap ruas saluran adalah sebesar 99,66\%. Standar Perencanaan Irigasi yang ditetapkan oleh Direktorat Jendral Pengairan, bahwa efisiensi irigasi pada saluran sekunder adalah sebesar $90 \%$ dengan rata - rata kehilangan air sebesar 5\% sampai dengan 10\%. Hal ini menunjukkan bahwa saluran irigasi BF 3 - BF 4 di BPU 15 sesuai dengan rencana.

Tabel 3

Efisiensi di saluran BF 3 - BF 4

\begin{tabular}{lllll}
\hline No & $\begin{array}{l}\text { Nama } \\
\text { saluran }\end{array}$ & $\begin{array}{l}\text { Debit hulu } \\
\left(\mathrm{m}^{3} / \mathrm{dtk}\right)\end{array}$ & $\begin{array}{l}\text { Debit hilir } \\
\left(\mathrm{m}^{3} / \mathrm{dtk}\right)\end{array}$ & $\begin{array}{l}\text { Efisiensi } \\
\text { saluran }(\%)\end{array}$ \\
\hline 1 & BF 3 Hilir & 0,6490 & 0,6417 & 98,88 \\
2 & STA +100 & 0,6417 & 0,6404 & 99,79 \\
3 & STA +200 & 0,6404 & 0,6397 & 99,90 \\
4 & STA +300 & 0,6397 & 0,6390 & 98,89 \\
5 & STA +400 & 0,6390 & 0,6383 & 99,89 \\
6 & BF 4 Hulu & 0,6383 & 0,6361 & 99,65 \\
Efisiensi Rata-rata & & & 99,66 \\
\hline
\end{tabular}

Berdasarkan hasil perhitungan di saluran irigasi BF 4 BF 5 di Tabel 4, menunjukkan bahwa efisiensi terkecil terjadi pada saluran STA +1400 dengan nilai efisiensi sebesar $99,20 \%$ dan efisiensi terbesar terjadi pada saluran STA +1600 dengan nilai efisiensi sebesar 99,61\%. Efisiensi rata - rata yang tercapai untuk tiap ruas saluran adalah sebesar 99,39\%. Standar Perencanaan Irigasi yang ditetapkan oleh Direktorat Jendral Pengairan, bahwa efisiensi irigasi pada saluran sekunder adalah sebesar $90 \%$ dengan rata - rata kehilangan air sebesar 5\% sampai dengan $10 \%$. Hal ini menunjukkan bahwa saluran irigasi BF 4 - BF 5 di BPU 15 sesuai dengan rencana.

Tabel 4

Efisiensi di saluran BF 4 - BF 5

\begin{tabular}{lllll}
\hline No & $\begin{array}{l}\text { Bukaan } \\
\text { pintu } \\
(\mathrm{m})\end{array}$ & $\begin{array}{l}\text { Debit BF4 } \\
\text { hilir } \\
\left(\mathrm{m}^{3} / \mathrm{s}\right)\end{array}$ & $\begin{array}{l}\text { Debit BF5 } \\
\text { hulu } \\
\left(\mathrm{m}^{3} / \mathrm{s}\right)\end{array}$ & $\begin{array}{l}\text { Efisiensi } \\
\text { saluran } \\
(\%)\end{array}$ \\
\hline 1 & BF 4 Hilir & 0,3203 & 0,3186 & 46,49 \\
2 & STA +200 & 0,3186 & 0,3183 & 99,48 \\
3 & STA +400 & 0,3183 & 0,3163 & 99,28 \\
4 & STA +600 & 0,3163 & 0,3146 & 99,45 \\
5 & STA +800 & 0,3146 & 0,3129 & 99,46 \\
6 & STA +1000 & 0,3129 & 0,3105 & 99,23 \\
7 & STA +1200 & 0,3105 & 0,3088 & 99,46 \\
8 & STA +1400 & 0,3088 & 0,3063 & 99,20 \\
9 & STA +1600 & 0,3063 & 0,3051 & 99,61 \\
10 & BF 5 Hulu & 0,3051 & 0,3028 & 99,26 \\
Efisiensi Rata-rata & & & 99,39 \\
\hline
\end{tabular}

\subsection{Faktor yang mempengaruhi kehilangan air}

Jumlah air yang sampai pada suatu areal pertanian dalam skala waktu tertentu mengalami pengurangan sepanjang saluran yang dilaluinya. Berdasarkan pengamatan ditemukan beberapa titik di sepanjang saluran yang kondisinya telah mengalami retak dan pecah, tumbuhnya tanaman liar di dinding saluran, serta banyak sampah yang menumpuk di dalam saluran, dan adanya upaya pencurian air irigasi yang dilakukan masyarakat untuk keperluan pribadi, sehingga pada saat penyaluran air di areal irigasi kemungkinan tidak dapat tersalurkan dengan baik.

Tabel 5 memperlihatkan bahwa kehilangan air yang terjadi akibat pencurian air cukup bervariasi. Pada saat pintu dibuka $2 \mathrm{~cm}$ yaitu pada tanggal 01 Oktober 2018 pada pukul 14.40 WIB, saluran BF 3 - BF 4 mengalami kehilang- an air sebesar $14,15 \%$ atau 0,0214 $\mathrm{m}^{3} / \mathrm{s}$. Kemudian kehilangan air mengalami kenaikan yang cukup signifikan pada saat memasuki saluran BF 4 - BF 5 pada pukul 15.20 WIB yaitu sebesar $53,72 \%$ atau $0,0213 \mathrm{~m}^{3} / \mathrm{s}$. Pada saat pintu dibuka $4 \mathrm{~cm}$ yaitu pada pukul 16.00 WIB kehilangan air yang terjadi pada saluran BF 3 - BF 4 sebesar 15,37\% atau $0,0276 \mathrm{~m}^{3} / \mathrm{s}$. Kemudian mengalami kenaikan kembali pada saat memasuki saluran BF 4 - BF 5 pada pukul 16.45 WIB yaitu sebesar $54,51 \%$ atau $0,0229 \mathrm{~m}^{3} / \mathrm{s}$.

\section{Tabel 5}

Kehilangan air akibat pencurian air

\begin{tabular}{|c|c|c|c|c|c|c|c|c|c|}
\hline \multirow[b]{2}{*}{ No. } & \multirow[b]{2}{*}{ Saluran } & \multirow{2}{*}{$\begin{array}{c}\text { Bukaan } \\
\text { Pintu } \\
\text { (m) }\end{array}$} & \multirow[b]{2}{*}{ Tanggal } & \multicolumn{2}{|c|}{ Hilir } & \multicolumn{2}{|c|}{ Hulu } & \multirow{2}{*}{$\begin{array}{c}\text { Kehilangan } \\
\left(\mathrm{m}^{3} / \mathrm{s}\right)\end{array}$} & \multirow{2}{*}{$\begin{array}{c}\text { Persentase } \\
\text { Kehilangan } \\
(\%)\end{array}$} \\
\hline & & & & $\begin{array}{l}\text { Debit } \\
\left(\mathrm{m}^{3} / \mathrm{s}\right)\end{array}$ & Jam & $\begin{array}{l}\text { Debit } \\
\left(\mathrm{m}^{3} / \mathrm{s}\right)\end{array}$ & Jam & & \\
\hline 1 & BF 3-BF 4 & 0,02 & $01 / 10 / 2018$ & 0,1512 & 14.40 & 0,1298 & 15.00 & 0,0214 & 14,15 \\
\hline 2 & BF 4-BF 5 & 0,02 & 01/10/2018 & 0,0396 & 15.20 & 0,0183 & 15.40 & 0,0213 & 3,72 \\
\hline 3 & BF 3-BF 4 & 0,04 & $01 / 10 / 2018$ & 0,1792 & 16.00 & 0,1516 & 16.20 & 0,0276 & 15,37 \\
\hline 4 & $\mathrm{BF} 4-\mathrm{BF} 5$ & 0,04 & 01/10/2018 & 0,0420 & 16.45 & 0,0191 & 17.15 & 0,0229 & 4,51 \\
\hline 5 & BF 4-BF 5 & 0,06 & $02 / 10 / 2018$ & 0,0732 & 09.40 & 0,0214 & 10.00 & 0,0518 & 70,79 \\
\hline 6 & BF 4-BF 5 & 0,08 & $02 / 10 / 2018$ & 0,0932 & 11.10 & 0,0768 & 11.30 & 0,0164 & 17,64 \\
\hline
\end{tabular}

Pada saat pintu dibuka $6 \mathrm{~cm}$ yaitu pada tanggal 02 Oktober 2018 pukul 09.40 WIB kehilangan air justru terjadi sangat besar pada saluran BF 4 - BF 5 yaitu sebesar 70,79\% atau $0,0518 \mathrm{~m}^{3} / \mathrm{s}$. Pada saat pintu dibuka $8 \mathrm{~cm}$ pada pukul 11.10 WIB kehilangan air pada saluran BF 4 - BF 5 mengalami penurunan menjadi $17,64 \%$ atau $0,0164 \mathrm{~m}^{3} / \mathrm{s}$. Namun justru berbanding terbalik dengan saluran BF 3 - BF 4 dimana pada tanggal 02 Oktober 2018 saluran tersebut justru mencapai nilai efisensi diatas $90 \%$.

Berdasarkan uraian tersebut jika dilihat dari besaran persentase kehilangan airnya terlihat bahwa kehilangan air yang terjadi pada saluran BF 3 - BF 4 lebih rendah daripada saluran BF 4 - BF 5 . Hal ini disebabkan karena saluran BF 4 - BF 5 berada dekat dengan pemukiman warga dan lebih banyak aktifitas yang terjadi. Selain itu jika dilihat dari waktu pengambilannya, aktifitas pencurian air secara liar ini terjadi pada waktu-waktu tertentu.

Pencurian air ini biasanya dilakukan dengan cara memasang pipa pada saluran irigasi kemudian memompa air dari saluran untuk mengairi lahan milik mereka. Jika hal ini dibiarkan terus menerus bukan tidak mungkin nantinya kehilangan air yang terjadi akan semakin besar. Pengambilan air irigasi secara liar merupakan salah satu kegiatan yang yang tidak dapat dibenarkan dan tentunya merugikan, terutama petani yang berada di hilir. Selain itu hal ini juga akan mempengaruhi debit dan efisiensi pada saluran yang akhirnya akan berpengaruh pada produksi tanaman.

Selanjutnya, kehilangan air juga disebabkan oleh faktor rembesan. Rembesan yang terjadi pada saluran dipengaruhi oleh panjang saluran, keliling basah saluran, kecepatan saluran dan bahan pelapis saluran. Perhitungan rembesan ini dilakukan dengan membagi jarak antar saluran untuk sekaligus meneliti kondisi saluran tersebut. Adapun hasil perhitungan kehilangan akibat faktor rembesan dapat disajikan pada Tabel 6 .

\section{Tabel 6}

Hasil perhitungan rembesan pada saluran BF 3 - BF 4

\begin{tabular}{llll}
\hline No & Nama saluran & $\begin{array}{l}\text { Rembesan } \\
(\mathrm{mm} / \text { hari })\end{array}$ & $\begin{array}{l}\text { Kategori } \\
\text { kerusakan }\end{array}$ \\
\hline 1 & BF3 Hilir & $6,988 \times 10^{-9}$ & Rusak Sedang \\
2 & STA +100 & $6,990 \times 10^{-9}$ & Rusak Sedang \\
3 & STA +200 & $6,402 \times 10^{-9}$ & Baik \\
4 & STA +300 & $6,404 \times 10^{-9}$ & Baik \\
5 & STA +400 & $6,662 \times 10^{-9}$ & Rusak Sedang \\
6 & BF 4 Hulu & $6,485 \times 10^{-9}$ & Rusak Ringan \\
\hline
\end{tabular}


Tabel 6 memperlihatkan bahwa nilai rembesan terbesar terjadi pada saluran STA+100 sebesar 6,990×10-9 mm/hari. Sedangkan nilai rembesan terkecil terjadi pada saluran STA+200 sebesar 6,402×10-9 mm/hari. Berdasarkan Tabel 6 dapat dilihat bahwa semakin baik kondisi saluran maka nilai rembesan yang terjadi akan semakin kecil dan begitupun sebaliknya, semakin parah kerusakan yang terjadi maka nilai rembesan juga akan semakin besar.

Tabel 7 memperlihatkan bahwa nilai rembesan terbesar terjadi pada saluran BF 4 - BF 5 STA+800 sebesar 6,667 x $10^{-9} \mathrm{~mm} /$ hari. Sedangkan nilai rembesan terkecil terjadi pada saluran BF 3 - BF 4 STA+1400 sebesar 4,604 x 10-9 $\mathrm{mm} /$ hari. Pada perhitungan menunjukkan bahwa kecepatan yang terjadi pada tiap ruas bervariasi sehingga menyebabkan hasil perhitungan yang bervariasi pula. Pada dasar saluran BF 4 - BF 5 yang belum dibuat lining memang terdapat lebih banyak rumput jika dibandingkan dengan saluran BF 3 - BF 4, hal inilah yang menyebabkan kecepatan yang terjadi pada tiap ruas bervariasi.

Tabel 7

Hasil perhitungan rembesan pada saluran BF 4 - BF 5

\begin{tabular}{llll}
\hline No & Nama saluran & $\begin{array}{l}\text { Rembesan } \\
\text { (mm/hari) }\end{array}$ & $\begin{array}{l}\text { Kategori } \\
\text { kerusakan }\end{array}$ \\
\hline 1 & BF 4 Hilir & $5,237 \times 10^{-9}$ & Baik \\
2 & +200 & $6,266 \times 10^{-9}$ & Baik \\
3 & +400 & $6,247 \times 10^{-9}$ & Baik \\
4 & +600 & $6,291 \times 10^{-9}$ & Baik \\
5 & +800 & $6,667 \times 10^{-9}$ & Rusak Ringan \\
6 & +1000 & $6,659 \times 10^{-9}$ & Baik \\
7 & +1200 & $5,167 \times 10^{-9}$ & Baik \\
8 & +1400 & $4,604 \times 10^{-9}$ & Baik \\
9 & +1600 & $5,806 \times 10^{-9}$ & Baik \\
10 & BF 5 Hulu & $5,755 \times 10^{-9}$ & Baik \\
\hline
\end{tabular}

Kehilangan air juga dapat disebabkan oleh faktor evaporasi. Analisis evaporasi dilakukan untuk mengetahui besarnya nilai evaporasi yang terjadi sepanjang saluran yang ditinjau. Analisis evaporasi menggunakan data klimatologi tahun 2018 yang bersumber dari Stasiun Meteorologi Radin Inten II. Adapun rumus yang digunakan pada perhitungan evaporasi ini menggunakan rumus empiris Penman dengan hasil perhitungan nilai evaporasi pada bulan oktober sebesar 2,23 mm/hari. Tabel 8 menunjukkan nilai evaporasi yang terjadi untuk tiap saluran.

Tabel 8

Hasil evaporasi permukaan air bebas saluran BF 3 - BF 4

\begin{tabular}{llll}
\hline No & $\begin{array}{l}\text { Nama } \\
\text { saluran }\end{array}$ & $\begin{array}{l}\text { Luas permukaan } \\
\text { air }\left(\mathrm{m}^{2}\right)\end{array}$ & $\begin{array}{l}\text { Evaporasi } \\
\left(\mathrm{m}^{3} / \mathrm{s}\right)\end{array}$ \\
\hline 1 & BF 3 Hilir & 267,00 & $6,90 \times 10^{-6}$ \\
2 & +100 & 267,00 & $6,90 \times 10^{-6}$ \\
3 & +200 & 280,00 & $7,23 \times 10^{-6}$ \\
4 & +300 & 280,00 & $7,23 \times 10^{-6}$ \\
5 & +400 & 295,00 & $7,62 \times 10^{-6}$ \\
6 & BF 4 Hulu & 274,40 & $7,09 \times 10^{-6}$ \\
\hline
\end{tabular}

Berdasarkan data pada Tabel 8 tersebut diketahui bahwa nilai evaporasi permukaan air bebas saluran BF 3 BF 4 terbesar terjadi pada STA+400 yaitu sebesar 7,62 x 10$6 \mathrm{~m} 3 / \mathrm{s}$. Sedangkan nilai evaporasi permukaan air bebas saluran terkecil terjadi pada saluran $\mathrm{BF} 3$ Hilir dan STA+100 yaitu sebesar $6,90 \times 10-6 \mathrm{~m}^{3} / \mathrm{s}$. Tabel 8 memperlihatkan bahwa nilai evaporasi pada saluran ditentukan pada luas permukaan yang ditinjau. Semakin luas saluran maka nilai evaporasi akan semakin besar pula.
Dari data pada Tabel 9 diketahui bahwa nilai evaporasi permukaan air bebas saluran $\mathrm{BF} 4-\mathrm{BF} 5$ terbesar terjadi pada STA+800 sampai dengan STA +1000 yaitu sebesar $1,70 \times 10-5 \mathrm{~m}^{3} / \mathrm{s}$. Sedangkan nilai evaporasi permukaan air bebas saluran terkecil terjadi pada saluran BF 5 Hulu yaitu sebesar $1,15 \times 10-5 \mathrm{~m}^{3} / \mathrm{s}$. Tabel 9 memperlihatkan bahwa nilai evaporasi pada saluran ditentukan pada luas permukaan yang ditinjau. Semakin luas saluran maka nilai evaporasi akan semakin besar pula.

\section{Tabel 9}

Hasil evaporasi permukaan air bebas saluran BF 4 - BF 5

\begin{tabular}{|l|l|l|l|}
\hline No & $\begin{array}{l}\text { Nama } \\
\text { saluran }\end{array}$ & $\begin{array}{l}\text { Luas permukaan } \\
\text { air }\left(\mathrm{m}^{2}\right)\end{array}$ & $\begin{array}{l}\text { Evaporasi } \\
\left(\mathrm{m}^{3} / \mathrm{s}\right)\end{array}$ \\
\hline 1 & BF 4 Hilir & 480,00 & $1,24 \times 10^{-5}$ \\
2 & +200 & 546,00 & $1,41 \times 10^{-5}$ \\
3 & +400 & 556,00 & $1,44 \times 10^{-5}$ \\
4 & +600 & 556,00 & $1,44 \times 10^{-5}$ \\
5 & +800 & 660,00 & $1,70 \times 10^{-5}$ \\
6 & +1000 & 660,00 & $1,70 \times 10^{-5}$ \\
7 & +1200 & 540,00 & $1,39 \times 10^{-5}$ \\
8 & +1400 & 460,00 & $1,19 \times 10^{-5}$ \\
9 & +1600 & 574,00 & $1,48 \times 10^{-5}$ \\
10 & BF 5 Hulu & 445,20 & $1,15 \times 10^{-5}$ \\
\hline
\end{tabular}

Selanjutnya Tabel 10 menunjukkan nilai kehilangan air pada saluran BF 3 - BF 4 terbesar terjadi pada saluran BF 3 Hilir sebesar $0,0072 \mathrm{~m}^{3} / \mathrm{s}$ atau sebesar $1,13 \%$. Sedangkan nilai kehilangan air terkecil terjadi pada saluran STA+200 sebesar $0,0007 \mathrm{~m}^{3} / \mathrm{s}$ atau sebesar $0,10 \%$. Faktor rembesan memiliki nilai rata - rata paling besar dalam mempengaruhi kehilangan air pada saluran BF 3 - BF 4 yaitu sebesar $53,74 \%$. Sedangkan faktor evaporasi mempengaruhi kehilangan air sebesar 0,69\% dan faktor lain - lainnya sebesar 46,57\%. Pengaruh hilangnya air akibat evaporasi tidak terlalu signifikan terjadi, namun nilai kehilangan air akibat rembesan tergolong besar. Hal ini dipengaruhi oleh kondisi fisik saluran yang dilalui air. Sedangkan pada beberapa titik saluran mengalami nilai kehilangan air yang tergolong besar akibat faktor lainnya seperti yang terjadi pada saluran BF 3 Hilir, STA+100, dan BF 4 Hulu.

\section{Tabel 10}

Persentase kehilangan air pada saluran BF 3 - BF 4

\begin{tabular}{|c|c|c|c|c|c|c|}
\hline \multirow{2}{*}{ No. } & \multirow{2}{*}{ Saluran } & \multicolumn{2}{|c|}{ Debit Hilang Total } & \multicolumn{3}{c|}{ Persentase Kehilangan Air } \\
\cline { 3 - 7 } & & $\left(\mathrm{m}^{3} / \mathrm{s}\right)$ & $(\%)$ & $\begin{array}{c}\text { Rembesan } \\
(\%)\end{array}$ & $\begin{array}{c}\text { Evaporasi } \\
(\%)\end{array}$ & $\begin{array}{c}\text { Faktor Lain } \\
(\%)\end{array}$ \\
\hline 1 & BF 3 Hilir & 0,0072 & 1,13 & 8,34 & 0,10 & 91,57 \\
2 & +100 & 0,0013 & 0,21 & 45,36 & 0,52 & 54,12 \\
3 & +200 & 0,0007 & 0,10 & 83,70 & 1,09 & 15,21 \\
4 & +300 & 0,0007 & 0,11 & 79,17 & 1,03 & 19,80 \\
5 & +400 & 0,0007 & 0,11 & 80,67 & 1,07 & 18,26 \\
6 & BF 4 Hulu & 0,0022 & 0,35 & 25,20 & 0,32 & 74,48 \\
\hline \multicolumn{2}{|c|}{ Rata - rata } & $\mathbf{5 3 , 7 4}$ & $\mathbf{0 , 6 9}$ & $\mathbf{4 5 , 5 7}$ \\
\hline
\end{tabular}

Tabel 11 menunjukkan nilai kehilangan air pada saluran BF 4 - BF 5 terbesar terjadi pada saluran STA+1400 sebesar $0,0025 \mathrm{~m}^{3} / \mathrm{s}$ atau sebesar $0,8 \%$. Sedangkan nilai kehilangan air terkecil terjadi pada saluran STA+1600 sebesar 0, 0012 $\mathrm{m} 3 / \mathrm{s}$ atau sebesar $0,4 \%$. Pengaruh hilangnya air akibat rembesan pada saluran BF 4 - BF 5 sebesar 27,85\%. Sedangkan kehilangan air akibat evaporasi tidak terlalu signifikan terjadi yaitu sebesar $0,78 \%$. Kehilangan air akibat faktor lainnya menjadi pengaruh paling besar yaitu sebesar 71,37\%. Dari hasil analisis dapat disimpulkan bahwa nilai kehilangan air secara keseluruhan pada Saluran BF 4 - BF 5 terbesar terjadi akibat adanya faktor lain, seperti penumpukan sampah pada saluran, adanya upaya 
pencurian air irigasi oleh masyarakat, dan tumbuhnya tanaman liar disepanjang saluran.

Tabel 11

Persentase kehilangan air pada saluran BF 4 - BF 5

\begin{tabular}{lllllll}
\hline \multirow{2}{*}{ No } & Saluran & \multicolumn{3}{l}{ Debit hilang total } & \multicolumn{3}{l}{ Persentase kehilangan air } \\
\cline { 3 - 7 } & & $\left(\mathrm{m}^{3} / \mathrm{s}\right)$ & $(\%)$ & $\begin{array}{l}\text { Rembesan } \\
(\%)\end{array}$ & $\begin{array}{l}\text { Evaporasi } \\
(\%)\end{array}$ & $\begin{array}{l}\text { Faktor } \\
\text { lain (\%) }\end{array}$ \\
\hline 1 & BF 4 Hilir & 0,0017 & 0,52 & 27,30 & 0,75 & 71,95 \\
2 & +200 & 0,0017 & 0,52 & 32,66 & 0,85 & 66,49 \\
3 & +400 & 0,0023 & 0,72 & 23,58 & 0,63 & 75,79 \\
4 & +600 & 0,0017 & 0,55 & 31,14 & 0,82 & 68,04 \\
5 & +800 & 0,0017 & 0,54 & 33,84 & 1,00 & 65,16 \\
6 & +1000 & 0,0024 & 0,78 & 23,78 & 0,70 & 75,51 \\
7 & +1200 & 0,0017 & 0,55 & 26,44 & 0,83 & 72,74 \\
8 & +1400 & 0,0025 & 0,80 & 16,19 & 0,48 & 83,33 \\
9 & +1600 & 0,0012 & 0,40 & 41,53 & 1,23 & 57,24 \\
10 & BF 5 Hulu & 0,0023 & 0,74 & 22,08 & 0,51 & 77,41 \\
\multicolumn{2}{l}{ Rata - rata } & & & $\mathbf{2 7 , 8 5}$ & $\mathbf{0 , 7 8}$ & $\mathbf{7 1 , 3 7}$ \\
\hline
\end{tabular}

\section{Simpulan}

Hasil penelitian menunjukkan bahwa kerusakan pada saluran BF 3 - BF 4 sebesar 19\% dan termasuk dalam kategori Rusak Ringan. Sedangkan kerusakan pada saluran BF 4 - BF 5 adalah sebesar $5 \%$ dan termasuk kedalam kategori "baik". Adapun jenis kerusakan yang terjadi yaitu adanya lubang pada beberapa titik di sepanjang saluran dengan kondisi yang berbeda - beda. Selain itu, di sekitar saluran terdapat tumbuhan semak belukar yang merupakan tumbuhan yang banyak memerlukan air, sehingga air yang merembes dari saluran akan diserap oleh akar tanaman.

Selain itu, efisiensi rata - rata pada saluran BF 3 - BF 4 berdasar-kan simulasi bukaan pintu sebesar 97,41\% yang artinya terjadi kehilangan air sebesar 2,59\%. Sedangkan efisiensi rata - rata pada saluran BF 4 - BF 5 sebesar $87,69 \%$ dimana terjadi kehilangan air sebesar $12,31 \%$.

Persentase kehilangan air pada saluran BF 3 - BF 4 akibat faktor rembesan sebesar $53,74 \%$, faktor evaporasi sebesar 0,69\% dan faktor lain - lainnya sebesar 46,57\%. Sedangkan untuk persentase kehilangan air pada saluran BF 4 - BF 5 akibat faktor rembesan sebesar $27,85 \%$, faktor evaporasi sebesar $0,78 \%$ dan faktor lain - lainnya sebesar $71,37 \%$.

\section{Daftar Pustaka}

[1] Marpaung, L.: Evaluasi jaringan saluran irigasi Paya Sordang Kabupaten Tapanuli Selatan. Skripsi, Universitas Medan Area, 2016

[2] Sutrisno, Chayati, C.: Perhitungan efisiensi saluran irigasi pada daerah irigasi Kebonagung Kabupaten Sumenep. Jurnal, Universitas Wiraraja, Sumenep, 2011

[3] Sembiring, C.E.: Analisi debit air irigasi (suplai dan kebutuhan) di Sekampung Sistem. Universitas Lampung. Lampung, 2016

[4] Kurnia: Hemat air irigasi: kebijakan, teknik, pengelolaan dan sosial budaya, Pusat Dinamika Pembangunan Universitas Padjajaran, Bandung, 1991

[5] Soemart: Hidrologi teknik-edisi ke-2. Penerbit Erlangga, Jakarta, 1999

[6] Wilhelmus, B.: Analisis efisiensi dan kehilangan air pada jariringan utama daerah irigasi air sagu. Jurnal Teknik Sipil, 2011

[7] Siswoyo, H., Wahyudi, I., Soedarsono: Analisis efisiensi jaringan saluran irigasi di daerah irigasi Kabuyutan (studi kasus di Kabupaten Brebes). Universitas Islam Sultan Agung, Semarang, 2017 